PRACE GEOGRAFICZNE

zeszyt 151, 2017, 93-119

doi: $10.4467 / 20833113$ PG.17.024.8036

Instytut Geografii i Gospodarki Przestrzennej UJ

Wydawnictwo Uniwersytetu Jagiellońskiego

\title{
CHANGES IN DISCHARGE REGIMES IN THE MIDDLE COURSE OF THE SAVA RIVER IN THE 1931-2010 PERIOD
}

\author{
Danijel Orešić, Ivan Čanjevac, Mladen Maradin
}

\begin{abstract}
In order to analyse discharge regimes in the middle course of the Sava River (Croatia and Bosnia and Herzegovina), three hydrologic stations were chosen, having homogenous as well as continuous data in the observed 1931-2010 period. Those stations are Rugvica at the beginning of the middle course of the Sava River, station Jasenovac located just forehead of the Una River mouth and all the other large tributaries from Bosnia and Herzegovina and station Županja near the end of the middle course of the Sava River. At all three stations, there are notable negative trends of annual mean (all stat. significant) and minimum discharges for the whole period. At the same time, only in the upper part of the middle course of the Sava River maximum annual discharges have a positive trend, contributing to more unfavourable regime characteristics. At all three stations a cyclic variation of mean annual discharges is observed, likely to be linked to the cyclic variation of annual precipitation in the area of the basin. According to the latest discharge regime typology of the region the discharge regime at Rugvica is of Peripannonian pluvial-nival type, while the discharge regimes downstream, at Jasenovac and Županja fall into Pannoninan pluvial-nival type. A comparison of discharge regimes established for two past climatological standard reference periods 1931-1960 and 1961-1990 as well as for the contemporary 30-year period 1981-2010 lead to a conclusion that important changes in mean monthly discharges yearly course already occurred in the climatological standard reference period 1961-1990 compared to the previous one. In 1961-1990 period the autumn season discharge decreased, which is almost solely a result of a large fall in the November mean monthly discharge at all stations. Furthermore, in the same 1961-1990 period a transition of the primary maximum in the annual course of mean monthly discharges from November to December and of the secondary maximum from March to April occurred, which is preserved in discharge regimes in the middle course of the Sava River. Discharge regimes in the middle course of the Sava River in the contemporary period are characterised by decreased summer and even spring time discharges, which is linked to the trend of raising
\end{abstract}


air temperatures, an increase in potential and real evapotranspiration and to a slowly decrease in annual precipitation, particularly in the summer season as established in spatially relevant previous climatological research.

Keywords: discharge regime, discharge trends, the Sava River basin, hydrogeography, hydrology

\section{Introduction}

The Sava River is one of the most important rivers in Europe, especially in the Southeastern Europe, being the third longest and the largest by discharge tributary of the Danube River. According to International Sava River Basin Commission data (ISRBC, n.d.) the Sava River is $944 \mathrm{~km}$ long and its catchment covers $97713 \mathrm{~km}^{2}$. With its average discharge of about $1564 \mathrm{~m}^{3} \cdot \mathrm{s}^{-1}$, the Sava River is the most water abundant Danube tributary and the 8 th by water volume in Europe. It rises in the Julian Alps in Slovenia and it bears its name Sava from the confluence of its headwaters - the Sava Dolinka (50.5 km long system) and the Sava Bohinjka (41 km long system). The Sava Dolinka is considered as the Sava River source, ultimately fed by the Nadiža creek spring at $1222 \mathrm{~m}$ above sea level. The Sava River flows in a general direction to the south-east and east, running through Slovenia, Croatia, Bosnia and Herzegovina and finally into Serbia where it flows into the Danube River as its right tributary, at Belgrade at $67 \mathrm{~m}$ above sea level.

The Sava River is the main water collector in this part of Europe, as its basin covers altogether six states (Tab. 1). It drains $75 \%$ of the Bosnia and Herzegovina territory, $53 \%$ of the Slovenian, $50 \%$ of Montenegrin, $45 \%$ of Croatian territories, still considerable $17 \%$ of the Serbian territory and a small part of the Albanian territory.

An estimated 8.2 million people live in the Sava River basin, comprising almost half of the total population of Slovenia, Croatia, Bosnia and Herzegovina and Serbia. Also, almost half of the workers of those states are employed inside the Sava River basin (ISRBC, 2013a). Those four states capitals are in the Sava catchment area and Sava connects three of them, Ljubljana, Zagreb and Belgrade.

The Sava River valley is historically an important communication route between Central and Southeastern Europe and today it is among the major European transport corridors. The development of modern transportation infrastructure led to considerable population concentration and growth of modern cities as well as to propulsion of diverse economic activities often spatially competitive so that the Sava River valley today is under tremendous anthropogenic pressure and its remaining natural habitats are endangered. It is worrying that its open aquifer is especially under pressure, although it is a major source for water supply of all the large cities along its course and even for the settlements quite far from it. 
Table 1. The Sava River basin and the sharing states areal data

\begin{tabular}{|c|c|c|c|c|c|c|}
\hline & Slovenia & Croatia & $\begin{array}{c}\text { Bosnia and } \\
\text { Herzegovina }\end{array}$ & Serbia & Montenegro & Albania \\
\hline Total country area [km²] & 20.273 & 56.542 & 51.129 & 88.361 & 13.812 & 27.398 \\
\hline $\begin{array}{c}\text { Area of the country in the Sava } \\
\text { RB [km²] }\end{array}$ & 11.734 .8 & 25.373 .5 & 38.349 .1 & 15.147 & 6.929 .8 & 179 \\
\hline $\begin{array}{c}\text { Share of national territory in the } \\
\text { Sava RB [\%] }\end{array}$ & 52.80 & 45.20 & 75.80 & 17.40 & 49.60 & 0.59 \\
\hline $\begin{array}{c}\text { Share of the international Sava } \\
\text { RB [\%] }\end{array}$ & 12.01 & 25.97 & 39.25 & 15.50 & 7.09 & 0.18 \\
\hline
\end{tabular}

Source: ISRBC, Sava River Basin Management Plan 2013.

In spite of the anthropogenic pressures, the Sava River has still retained a quite outstanding biological and landscape diversity. Its central course hosts the largest complex of alluvial wetlands in the Danube basin and there are considerable lowland forests preserved. The Sava River is an example of a river with some of the natural floodplains still active and preserved. There are altogether as much as seven Ramsar sites in the Sava River basin and there are numerous protected areas at the national level and Natura 2000 sites.

It can be concluded that the Sava River is of multiple importance, in natural as well as in social and economic aspects. To establish sustainable water management in the basin, the Sava River basin sharing states concluded the Framework Agreement on the Sava River Basin (FASRB) which is an international agreement integrating all aspects of water management and established the (joint) International Sava River Basin Commission (ISRBC) for the implementation of the FASRB, with legal status of an international organization. The FASBR was signed in 2002 and it entered into force in 2004 after all states involved ratified the agreement. The interim Sava Commission worked from 2003, and a permanent ISRBC was formally established 2005 (www.savacomission.org).

\section{Reach and aims}

The research at hand is considered with the middle course of the Sava River, usually defined as the river course from the settlement of Rugvica, just downstream of Zagreb, the capital of Croatia, to the mouth of the Drina tributary, on the border 
between Bosnia and Herzegovina and Serbia ${ }^{1}$ (Fig. 1). The aim of this research is to analyse long-term changes in discharge regimes. River regime in hydrology typically describes the variability in discharge throughout the course of a year in response to precipitation, temperature, evapotranspiration, and drainage basin characteristics (Beckinsale 1969). In recent times, it is more often and more specifically analysed as discharge regime. Discharge regime implicit the ways in which a certain river is naturally water-fed as well as the yearly distribution of mean monthly and other characteristic discharges (Riđanović 1993; Čanjevac 2012, 2013).

\section{Previous research}

Considering relevant and more up- to-date research in the region, a valuable starting point can be established at the beginning of the 21 th century when several papers where published analysing long-term changes of discharge of rivers in Slovenia (Ulaga 2002; Frantar 2003, 2005; Frantar, Hrvatin, 2005; Ulaga et al. 2008). The general conclusion in those papers was that there is a general decrease in the maximum, mean and minimum discharges in almost all of Slovenia, with the only noticeable exception of the Eastern Slovenia. Decreasing long-term streamflow of

\footnotetext{
${ }^{1}$ There are some differences in literature concerning what is exactly concerned as the Sava River middle course, however it is that part of the river flowing through Croatia (and along its border with Bosnia and Herzegovina). Here it must be clear that a division of upper, middle and lower course is a geographical one, mainly hydromorphological and no other divisions baring the same name are considered, like those referring to public water management, sectors of flood defence or river navigation sectors. As for defining the Sava middle course, some sources state that the geographical border between upper and middle course is the mouth of the Sutla River, or practically where Sava enters Croatia (Croatian Encyclopedia online 2017), but this has no methodological foundation. In methodologically grounded sources which are dealing with this question the Sava at Rugvica settlement is given as the Sava River middle course starting point (Šterc 1979a, b; Riđanović 1983; Orešić 2008; ISRBC 2013b; Proleksis enciklopedija online 2013). The Sava River enters in Croatia less than a kilometre before the Sutla River mouth (left tributary) with an average yearly discharge of about $300 \mathrm{~m}^{3} \cdot \mathrm{s}^{-1}$ (hydrologic stations: Čatež in Slovenia $290 \mathrm{~m}^{3} \cdot \mathrm{s}^{-1}$, Podsused in Croatia $314 \mathrm{~m}^{3} \cdot \mathrm{s}^{-1}$ ). From the Sutla River mouth (at 720 Sava river kilometre), the Sava valley gets wider, and especially after the Podsused narrow (between Medvednica mountain and Samobor-Žumberak highlands) where it made a vast alluvial fan comprised of thick gravel deposits brought here by Sava in Pleistocene, during warmer interglacial and especially in early postpleistocen time. The Sava River flows on its alluvial fan with a steeper fall up to Rugvica settlement where there is a break point in its course: before Rugvica, the Sava river fall is $3.6 \mathrm{~m} / \mathrm{km}$ but after Rugvica it is only $0.04 \mathrm{~m} / \mathrm{km}$. Beside this geomorphological substantiation further support for Rugvica as a starting point of Sava middle course is found in sediment analysis. Namely, at Rugvica there is a quite sharp transition from very coarse and coarse gravel on the bottom of the river bed (upstream) into fine and very fine gravel and sand (downstream). Sources also differ as to where the Sava River middle course ends and lower course begins. Some give the Bosna River mouth (Croatian Encyclopaedia online 2017) or the Drina River mouth (ISRBC 2013b), and more related to navigation the settlement Sremska Mitrovica (ISRBC 2014). Hydrologically, the Drina River is the most influential Sava tributary, according to the discharge volume as well as by its sediment load, so we support this solution.
} 


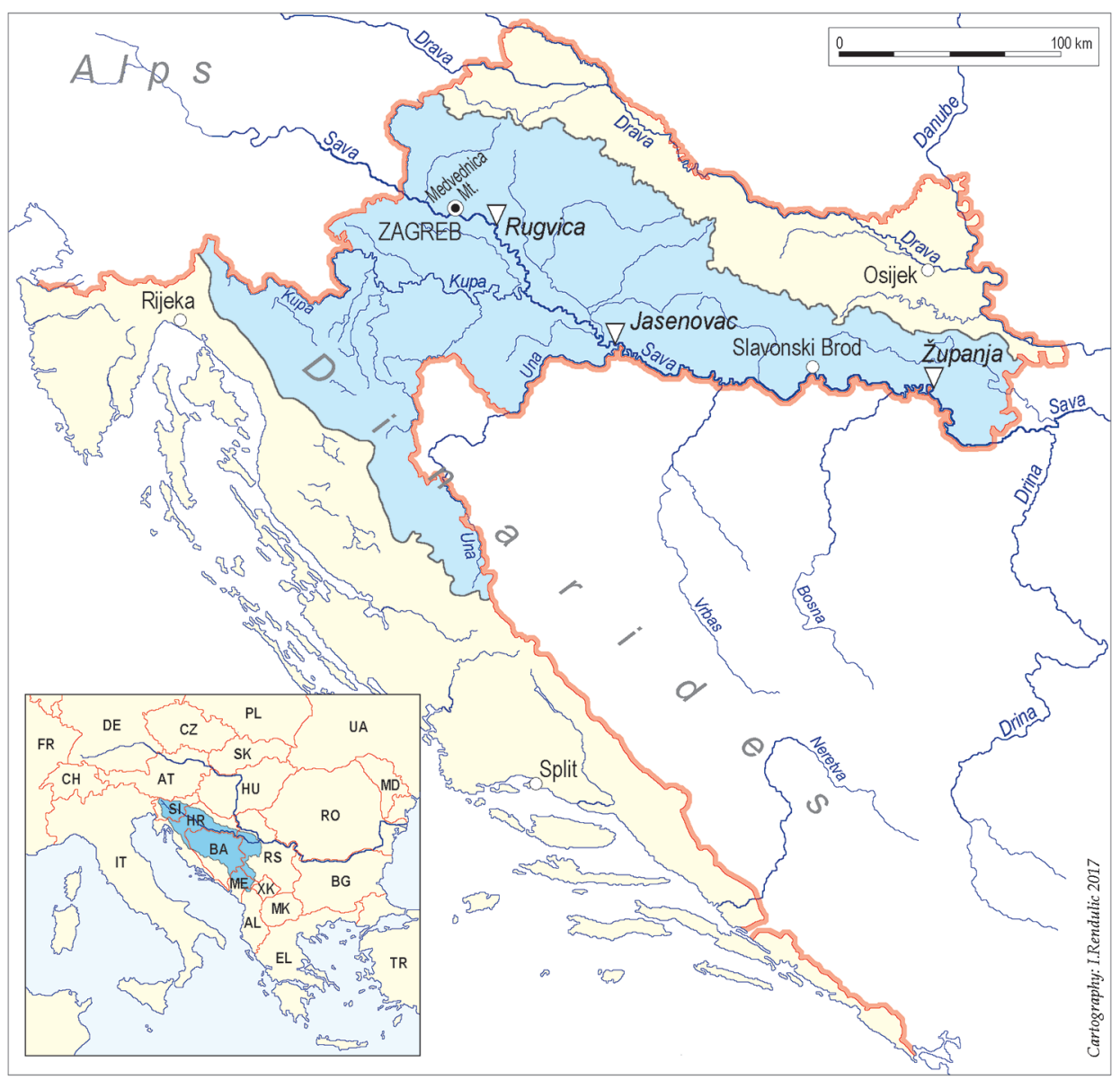

Fig. 1. The Sava River basin in Croatia with selected hydrological stations 
the Sava in Slovenia (at the Litija station) was confirmed most recently by Bezak et al. (2016). In the last 15 years research on discharge trends on major rivers intensified also in Croatia. Most research done on the Sava River has been concerned with the Sava at Zagreb, the capital of Croatia. Long-term changes of flood waters were investigated by Bonacci and Trninić (1991), Bonacci and Ljubenkov (2003, 2004, 2008) and Kratofil (2000), whereby they concluded that the discharge regime of the Sava at the Zagreb gauging station is under the influence of engineering works carried out as part of the flood protection system of the Zagreb city area. Characteristic discharges at Zagreb were analysed by Trninić and Bošnjak (2009), while Šegota and Filipčić (2007) pointed out that climate changes are reflected in discharge regime changes on the Sava at Zagreb. Due to the Bosnia and Herzegovina war between 1992 and 1995 and the post-war situation in that country there is a discontinuity in hydrological data of around ten years. Moreover, the gauging station network was practically lost; in 1999 there was only 1 automatic gauging station, today there are around 80 . Accordingly, not much hydrological research has been done concerning discharge regimes on the Sava River or any other river in Bosnia in Herzegovina in the last 20 years. In that sense, there is a valuable contribution by Korjenić (2014) on discharge regimes and water balance in the Una catchment and though it does not refer to changes it does present discharge regime characteristics on the Una River and the Sana River in the climatological standard reference period 1961-1990. It is notable that new and comprehensive hydrological studies are underway as planned by the contemporary legal documents in Bosnia and Herzegovina such as: Water management strategy of the Federation of Bosnia and Herzegovina (Federal Ministry of Agriculture, Water Management and Forestry et al., 2012), Integral water management strategy of the Republic of Srpska (JU Vode Srpske 2015) and the Sava River basin water management plan in the Federation of Bosnia and Herzegovina 2016-2021 (Agencija za vodno područje rijeke Save 2016). Of the Sava middle course tributaries, so far a hydrological study for the Bosna River (Federalni hidrometeorološki... 2012) catchment area was done and the main conclusions are much in accordance with conclusions presented here for the Sava River middle course. In the Bosna River catchment area study results include no significant changes in annual precipitation at the Sarajevo meteorological station in 1888-2009 period, rising mean annual air temperatures at all four analysed meteorological stations in the catchment area (at Sarajevo, Zenica, Tuzla and Doboj mean annual air temperatures have been increasing since 1951, more intensively in the 1991-2009 period) and lower mean monthly discharges at all four analysed gauging stations in the Bosna catchment from May to August in the2001-2009 period compared to the 1961-1990 climatological reference period.

At the level of Southeastern Europe there is a short but notable report from a Statkraft workshop held in Belgrade (Lawrence et al. 2009) presenting trends of 
decreasing discharges. Stahl et al. (2010) found positive trends over the winter months for most of the near-natural catchments around Europe along with some regional patterns, indicating decreasing (south, east) and increasing (elsewhere) trends in the European streamflow data. According to some climate change modelling for Southeastern Europe a decrease in precipitation is predicted (Arnell 2002). Hageman et al. (2013) present a possibility of a significant discharge decrease in Central and Southern Europe, and Stahl et al. (2012) in southern and eastern regions of Europe. However, even IPCC report (Hartmann et al. 2013) states that the decreasing discharge trends observed in the 20th century are statistically of a low level of confidence.

For the Sava River middle course reach, there are very few previous research dealing directly with discharge regime changes. Čanjevac (2012) analysed mean annual and seasonal discharge changes at twelve hydrological stations in the Croatian part of the Danube River basin, comparing contemporary state with previous 1961-1990 climatological reference period. Čanjevac and Orešić (2015) further analysed recent annual and seasonal discharge changes at 53 hydrological stations in Croatia for the 1990-2009 period. Previous research dealing with discharge regime on the Sava middle course include a hydrological analysis of measurements at the Slavonski Brod gauging station (Bonacci 2014) though mainly dealing with flood waters. For research at hand directly important results were presented by Pandžić et al. (2009) as well as Gajić-Čapka and her co-authors (Gajić-Čapka, Cindrić 2011, Gajić-Čapka et al. 2014) in the field of climatology. Those papers are necessary in understanding the causes of discharge regime changes in the region.

\section{Data and methods}

To analyse changes in discharge regimes it is best to observe data for a long period, so that we may find reflections of possible climate changes. This poses a problem in our investigated reach of the Sava River. Most of the nineteen hydrologic stations in middle course of the Sava River do have long-term data on water level, but they are not appropriate as water level can not be used in determining the discharge regime type. Having considered all, three hydrologic stations with available and homogenous time series where chosen, spaced well at the beginning of the Sava middle course, immediately before the mouth of the Una tributary (first of several large right tributaries form Dinaric Mountain area of Bosnia and Herzegovina) and near the end of the Sava River middle course. Those stations are, in order: Rugvica, Jasenovac and Županja (Tab. 2).

As for the time frame, it was decided to use the time series from 1931 to 2010 so that in addition to the contemporary period, two previous climatological standard reference periods, 1931-1960 and 1961-1990 could be considered. Discharge time 
Table 2. Basic information on selected hydrological stations in middle course of the Sava River

\begin{tabular}{|l|c|c|c|c|}
\hline $\begin{array}{c}\text { Hydrological } \\
\text { station }\end{array}$ & $\begin{array}{c}\text { River } \\
\text { kilometer }\end{array}$ & Basin area $\left(\mathrm{km}^{2}\right)$ & $\begin{array}{c}\text { Discharge (Q) measurement } \\
\text { (as up to 2015) }\end{array}$ & $\begin{array}{c}\text { No. of available annual SQ } \\
\text { in 1931-2010 period } \\
\text { (max N = 80) }\end{array}$ \\
\hline Rugvica & 636.6 & 12.730 & $\begin{array}{c}1926-1943,1946, \\
1948-1995,2000-2003, \\
2005,2007-2013,2015\end{array}$ & $\mathrm{~N}=71$ \\
\hline Jasenovac & 500.5 & 38.953 & $1926-1991,2007-2015$ & $\mathrm{~N}=74$ \\
\hline $\begin{array}{l}\text { Županja } \\
\text { stepenica }\end{array}$ & 262.0 & 62.891 & $1929-1942,1945-2015$ & $\mathrm{~N}=78$ \\
\hline
\end{tabular}

Source: Meteorological and Hydrological Service of Croatia.

series should be as continuous as possible and homogenous as it allows better results in statistical analyses in hydrology (Žugaj 2015). The homogeneity of available time series was tested by the commonly used Wilcoxon's test. The hydrologic time series where provided by the Hydrological Sector of the Meteorological and Hydrological Service of Croatia.

The research began with the analysis of the linear trends of mean annual discharge time series on mentioned hydrological stations for the whole period and comparing subperiods. The significance of trends was tested using the Mann-Kendall trend test. Moreover, the analysis of polynomial trend curve was used to assess periodicity. In addition, discharges in the form of seasonal sums of monthly mean values and in the form of percentage annual where analyzed for subperiods. Then, for each climatological standard reference period (1931-1960 and 1961-1990) as well as for contemporary period, discharge regimes at those stations were presented in the form of Parde monthly modular coefficients and changes analyzed. In fact, two contemporary periods where observed, a prolonged one into a 30-year 1981-2010 period with the idea of a better comparison of the contemporary state to earlier climatological standard reference periods, and a continued 20-year period from 1991 to 2010 which was used for a view on most recent changes.

\section{Results and discussion}

Contemporary discharge regimes at selected stations are determined observing variability in discharge throughout the course of a year on line charts (Fig. 2) presented not in actual discharge values but rather in the form of Parde monthly modular coefficients (monthly coefficient 1 means that the monthly discharge is equal to the 
yearly average discharge). The actual values for mean monthly discharges MQ and Parde monthly modular coefficients Mk are presented in table 3. There are data for the 1991-2010 period, since contemporary climatologic period starts with the year 1991. Only at the Županja hydrologic station the time series is complete, while on others they are incomplete (at Jasenovac 15 years, at Rugvica 14 years). Although the length of those incomplete series is enough to determine the discharge regime characteristics, in theory we can expect a greater deviation from representative values the shorter the time series are. To get a somewhat better presentation of the regime characteristics in the contemporary period it was decided to lengthen it to 30 years by a decade back in the past. That is why the modern discharge regimes are also presented by data from the 1981-2010 period. As expected, the differences between the two contemporary time series used are greater as there is less data for 1991-2010 period; the smallest difference is at Županja and the largest difference is at the Rugvica station. It is important to notice that those differences are not changing the basic regime characteristics, nor is choosing one over other influencing the main trends in regime changes compared to the previous climatologic standard reference period (1961-1990). However, the non-lengthened time series from 1991-2010 will provide some clues as to the nature of most recent changes.

Based on the most recent discharge regime typology in use in the region (Frantar, Hrvatin 2005; Čanjevac 2013), the discharge regime type changes along the course of the Sava River. Only the Sava's headwaters the Sava Dolinka and the Sava Bohinjka have the Alpine nival-pluvial regime. Downstream the Sava has the Peripannonian pluvial-nival regime which along the Sava River middle course gradually changes into the Pannonian pluvial-nival regime.

Accordingly, at the Rugvica station, at the starting point of the Sava middle course, we observe the Peripannonian pluvial-nival regime type. Basically, not engaging in more details (more detailed in: Čanjevac 2013) this type is characterised by a prominent primary maximum in the annual course of the mean monthly discharges in late fall or early winter, more precisely in December (rarely November) and by a secondary maximum in early spring, more precisely in March or April, partly formed by snowmelt runoff. Accordingly, contemporarily at the Rugvica station there is a primary maximum in December (not far behind in discharge share is November), and a secondary maximum in April. As we move downstream along the middle course of the Sava River the spring time discharge maximum becomes more and more prominent, meaning that the Peripannonian pluvial-nival regime is changing into the Pannonian pluvial-nival regime. Already at the hydrologic station Jasenovac the April discharge share is above all other months. However, if we observe the contemporary time series 1991-2010 at the Jasenovac station there is little difference between spring time and late-fall discharge maximums (Fig. 2; Tab. 3). 
Moreover, for the same station and a period differing by only one year (1990-2009) Čanjevac (2013) calculated a slightly higher December maximum, thus placing Jasenovac still in the Peripannonian pluvial-nival regime type. It is obvious to conclude that the change from the Peripannonian pluvial-nival to the Pannonian pluvial-nival regime type happens near Jasenovac, on the Sava River upstream of the Una tributary mouth. If we consult the work of Čanjevac (2013) we must conclude that there is an influence of the Kupa River which flows into Sava some 67 river kilometre upstream of Jasenovac as a first of many larger right-bank tributaries rising in the Dinaric area. The Kupa catchment shows complex runoff characteristics which together result in highest monthly discharges in November and December on the Kupa River, downstream of the Jamnica station. It can be concluded that the Sava River segment between the mouth of the Kupa River and the mouth of the Una River is the one with transitional characteristics between the Peripannonian and Pannonian pluvial-nival discharge regime types.

At the mouth of the Una River, the Sava continues its course as the border river between Croatia and Bosnia and Herzegovina. Along this section, the Sava receives several mainly smaller left tributaries from the Croatian Pannonian side and
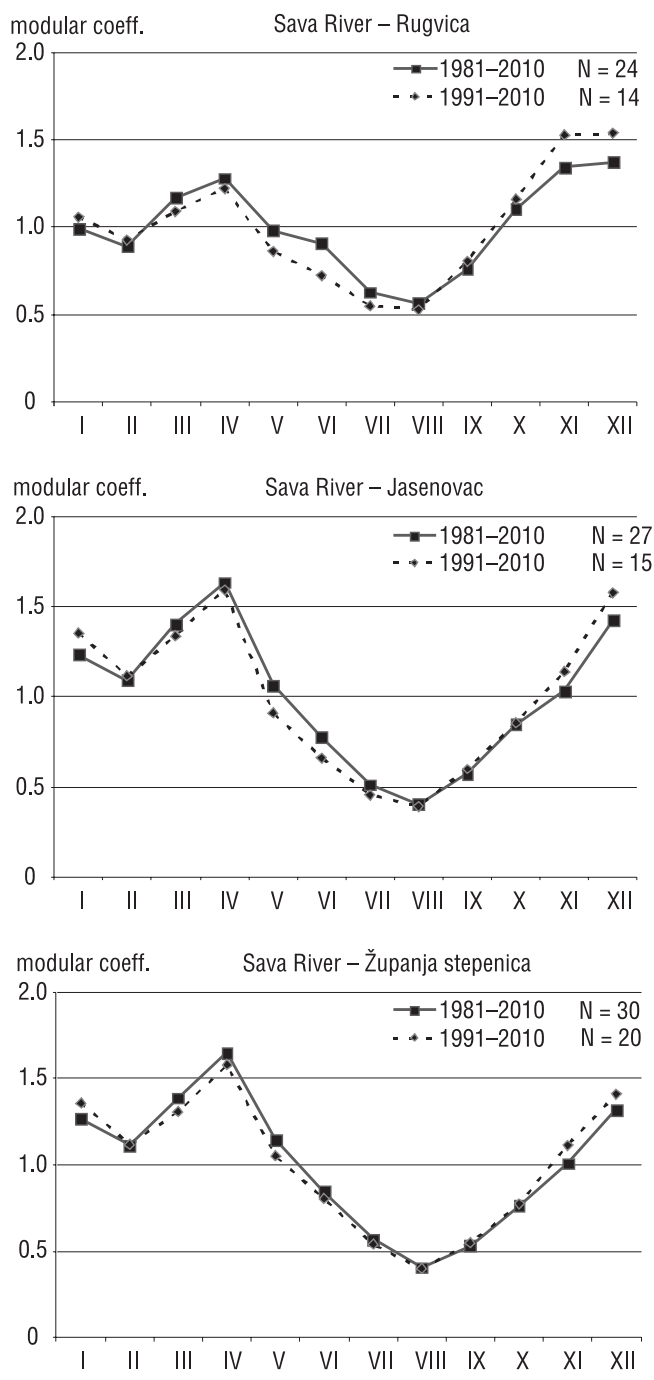

Fig. 2. Contemporary discharge regimes at selected stations in the middle course of the Sava River presented with Parde monthly modular coefficients

Source: Meteorological and Hydrological Service of Croatia. 
Table 3. Mean monthly discharges $\mathrm{MQ}\left(\mathrm{m}^{3} \cdot \mathrm{s}^{-1}\right)$ and Parde monthly modular coefficients (Mk) at the hydrological stations Rugvica, Jasenovac and Županja in the middle course of the Sava River in climatological standard reference periods and in the 20-year and 30-year contemporary periods

\begin{tabular}{|c|c|c|c|c|c|c|c|c|c|c|c|c|}
\hline & 1 & II & III & IV & V & VI & VII & VIII & IX & $x$ & XI & XII \\
\hline \multicolumn{13}{|c|}{ Rugvica } \\
\hline SQ (1931-1960) & 317.8 & 312.3 & 378.7 & 361.4 & 364.8 & 316.6 & 218.6 & 166.9 & 216.8 & 327.2 & 484.1 & 397.0 \\
\hline Mk & 0.99 & 0.97 & 1.18 & 1.12 & 1.13 & 0.98 & 0.68 & 0.52 & 0.67 & 1.02 & 1.50 & 1.23 \\
\hline SQ (1961-1990) & 285.0 & 301.7 & 354.8 & 419.7 & 340.8 & 303.4 & 238.8 & 184.8 & 227.2 & 303.1 & 377.2 & 346.3 \\
\hline Mk & 0.93 & 0.98 & 1.16 & 1.37 & 1.11 & 0.99 & 0.78 & 0.60 & 0.74 & 0.99 & 1.23 & 1.13 \\
\hline SQ (1981-2010) & 278.2 & 250.2 & 328.1 & 359.0 & 275.8 & 254.7 & 176.1 & 158.7 & 213.6 & 309.8 & 376.4 & 385.4 \\
\hline Mk & 0.99 & 0.89 & 1.17 & 1.28 & 0.98 & 0.91 & 0.63 & 0.57 & 0.76 & 1.10 & 1.34 & 1.37 \\
\hline SQ (1991-2010) & 297.1 & 261.5 & 307.2 & 343.6 & 242.7 & 203.8 & 154.8 & 148.7 & 226.5 & 325.6 & 429.4 & 432.1 \\
\hline Mk & 1.06 & 0.93 & 1.09 & 1.22 & 0.86 & 0.73 & 0.55 & 0.53 & 0.81 & 1.16 & 1.53 & 1.54 \\
\hline \multicolumn{13}{|c|}{ Jasenovac } \\
\hline SQ (1931-1960) & 868.4 & 927.2 & 1135.6 & 1053.7 & 896.9 & 724.0 & 471.1 & 313.1 & 357.4 & 628.7 & 1083.1 & 1024.9 \\
\hline Mk & 1.10 & 1.17 & 1.44 & 1.33 & 1.13 & 0.92 & 0.60 & 0.40 & 0.45 & 0.80 & 1.37 & 1.30 \\
\hline SQ (1961-1990) & 870.4 & 926.1 & 1022.1 & 1165.0 & 922.1 & 669.5 & 479.9 & 360.5 & 444.0 & 609.7 & 832.6 & 966.6 \\
\hline Mk & 1.13 & 1.20 & 1.32 & 1.51 & 1.19 & 0.87 & 0.62 & 0.47 & 0.57 & 0.79 & 1.08 & 1.25 \\
\hline SQ (1981-2010) & 801.5 & 709.2 & 912.9 & 1063.2 & 691.9 & 504.4 & 333.1 & 264.0 & 373.3 & 550.9 & 670.8 & 924.8 \\
\hline Mk & 1.23 & 1.09 & 1.40 & 1.64 & 1.06 & 0.78 & 0.51 & 0.41 & 0.57 & 0.85 & 1.03 & 1.42 \\
\hline SQ (1991-2010) & 849.1 & 700.0 & 839.2 & 1001.5 & 571.5 & 415.9 & 286.9 & 247.3 & 376.2 & 535.7 & 714.8 & 991.3 \\
\hline Mk & 1.35 & 1.12 & 1.34 & 1.60 & 0.91 & 0.66 & 0.46 & 0.39 & 0.60 & 0.85 & 1.14 & 1.58 \\
\hline \multicolumn{13}{|c|}{ Županja stepenica } \\
\hline SQ (1931-1960) & 1370.0 & 1452.8 & 1838.3 & 1748.6 & 1482.7 & 1146.1 & 742.4 & 492.8 & 515.9 & 821.8 & 1461.8 & 1460.5 \\
\hline Mk & 1.13 & 1.20 & 1.52 & 1.44 & 1.22 & 0.95 & 0.61 & 0.41 & 0.43 & 0.68 & 1.21 & 1.21 \\
\hline SQ (1961-1990) & 1302.0 & 1437.4 & 1552.6 & 1782.2 & 1465.8 & 1017.6 & 707.4 & 503.3 & 589.9 & 792.7 & 1079.7 & 1379.2 \\
\hline Mk & 1.15 & 1.27 & 1.37 & 1.57 & 1.29 & 0.90 & 0.62 & 0.44 & 0.52 & 0.70 & 0.95 & 1.22 \\
\hline SQ (1981-2010) & 1330.6 & 1169.6 & 1457.8 & 1733.1 & 1204.2 & 886.4 & 595.2 & 425.4 & 557.4 & 801.2 & 1058.5 & 1385.9 \\
\hline Mk & 1.27 & 1.11 & 1.39 & 1.65 & 1.15 & 0.84 & 0.57 & 0.40 & 0.53 & 0.76 & 1.01 & 1.32 \\
\hline SQ (1991-2010) & 1460.4 & 1202.2 & 1406.0 & 1698.5 & 1129.2 & 862.3 & 579.7 & 431.0 & 588.9 & 833.2 & 1199.3 & 1517.4 \\
\hline Mk & 1.36 & 1.12 & 1.31 & 1.58 & 1.05 & 0.80 & 0.54 & 0.40 & 0.55 & 0.77 & 1.11 & 1.41 \\
\hline
\end{tabular}

Source: Meteorological and Hydrological Service of Croatia. 
several large right tributaries from predominantly Dinaric Bosnia and Herzegovina. It is naturally in accordance with contemporary discharge characteristics of the Una River (Korjenić 2014) as well as other right tributaries from Bosnia and Herzegovina (ISRBC 2010, Federalni hidrometeorološki..., 2012) and left tributaries from Croatia (Čanjevac 2013) that downstream of the mouth of the Una River the discharge regime on the Sava is entirely the Pannonian pluvial-nival. This type is thus observed at the $\breve{Z}$ upanja station, most downstream of stations selected here, close to the endpoint of the Sava River middle course. The main differential characteristic of the Pannonian pluvial-nival regime is that the primary maximum in the annual course of the mean monthly discharges is in spring-time, regularly in the month of April with relatively high Parde modular coefficients (1.5 to 2), while the secondary maximum is regularly in December.

Research of the long-time discharge changes on the Sava River middle course began with analysing mean, maximum and minimum annual discharges time series at selected stations troughout the whole 1931-2010 period (Fig. 3).

On all three hydrographs, in the mean annual discharge time series we can observe a statistically significant trend of decreasing values in the whole 1931-2010 period (Tab. 4). At Rugvica a calculated negative linear trend for the whole period shows an annual decrease of $0.95 \mathrm{~m}^{3} \cdot \mathrm{s}^{-1}$, with the mean annual discharge in the whole period MQ (1931-2010) of $307.5 \mathrm{~m}^{3} \cdot \mathrm{s}^{-1}$. At Rugvica there is an annual decrease of $2.56 \mathrm{~m}^{3} \cdot \mathrm{s}^{-1}$ with the MQ (1931-2010) of $750.1 \mathrm{~m}^{3} \cdot \mathrm{s}^{-1}$ and at Županja an annual decrease of $2.97 \mathrm{~m}^{3} \cdot \mathrm{s}^{-1}$ with the MQ (1931-2010) of $1146.8 \mathrm{~m}^{3} \cdot \mathrm{s}^{-1}$.

The decreasing streamflow can be observed also by comparing the mean annual discharges (MQ) for consequent periods (Tab. 5). There is a significant drop of mean annual discharge at all stations between the climatological standard reference periods as well as between the climatological reference period 1961-1990 and both the 20-year and the 30-year (extended) contemporary periods. The relative decrease from the 1931-1960 average value to contemporary average value is about the same at Rugvica and Županja (about 13\%), and somewhat greater at Jasenovac (from about 18\% to almost 21\% in the case of comparing with the 30-year contemporary period). At all three stations, there is a decrease of the mean annual discharge already comparing the two climatological standard reference periods (1931-1960 to 1961-1990) but at Rugvica and especially Jasenovac stations the decrease is speeding up as can be concluded when reading the relative change values from any of two contemporary periods with the previous climatological reference period.

The observed long-term trend of decreasing mean annual discharges is upsetting, more so because on all three stations there is a negative long-term trend in annual minimum discharges too (Fig. 3; Tab. 4). It worries that in the same 1931-2010 period 

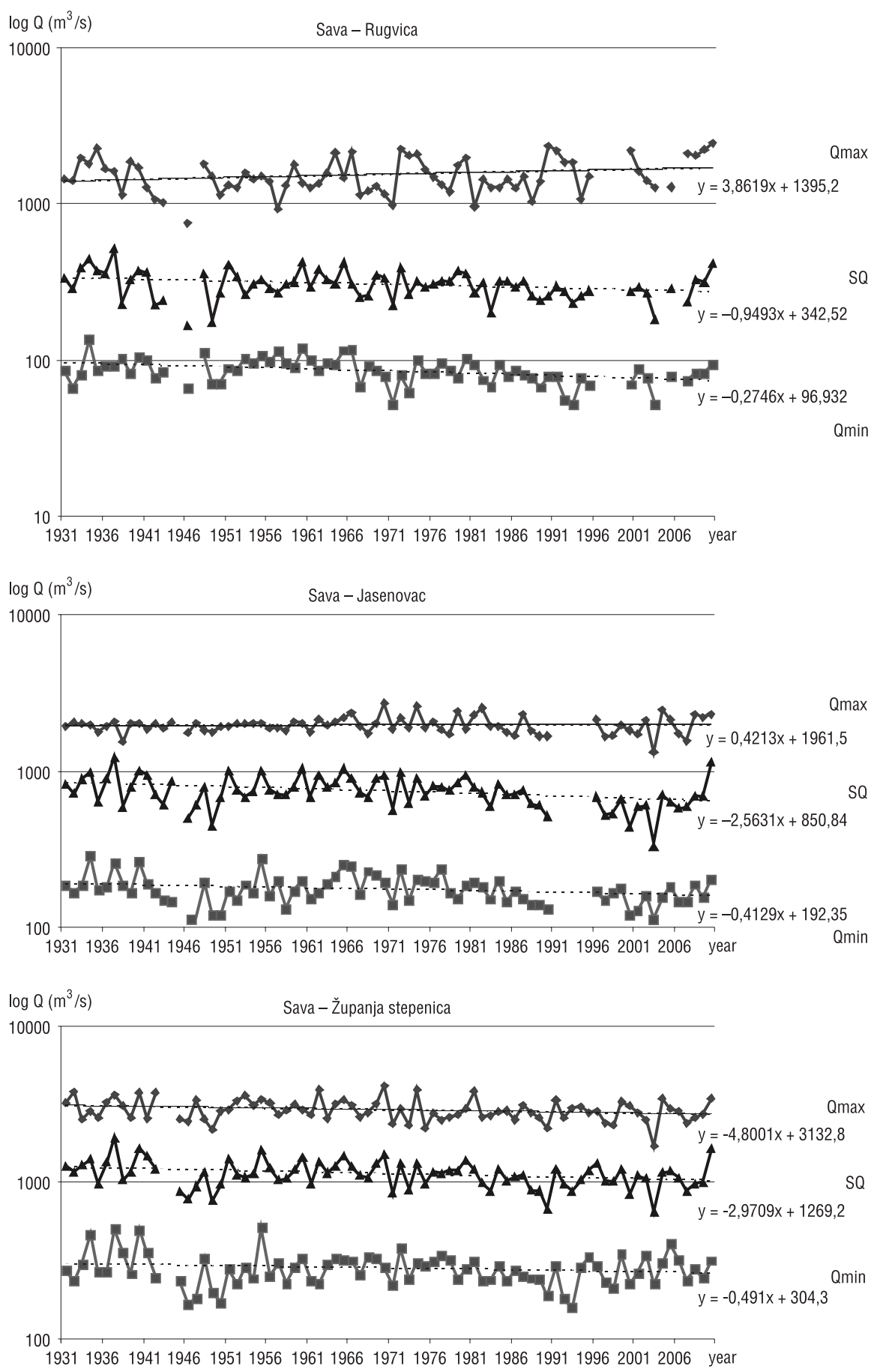
the annual maximum discharges are increasing at the Rugvica station and stagnant at the Jasenovac station. The growing difference between minimum and maximum annual discharges is an unfavourable characteristic of discharge regime as it equals larger variability in streamflow whereby in the case of stagnant (or even growing) discharge maximums the flood water occurrence and potential danger of flooding is not diminishing no matter the decreasing mean and minimum discharges. At the most downstream station Županja maximum annual discharges are decreasing in a trend similar to that of minimum annual discharges. This is because of a considerably larger catchment area at Županja, after several large tributaries joined

Table 5. Comparison of the mean discharge (SQ) values for the annual discharge time series in climatological standard reference periods and in the 20-year and 30-year contemporary periods at three selected hydrological stations in the middle course of the Sava River

\begin{tabular}{|c|c|c|c|}
\hline & Rugvica & Jasenovac & Županja \\
\hline $\mathrm{SQ}\left(\mathrm{m}^{3} \cdot \mathrm{s}^{1}\right) 1931-1960$ & 321.9 & 790.3 & 1211.1 \\
\hline $\mathrm{SQ}\left(\mathrm{m}^{3} \cdot \mathrm{s}^{1}\right) 1961-1990$ & 306.9 & 772.4 & 1134.2 \\
\hline $\mathrm{SQ}\left(\mathrm{m}^{3} \cdot \mathrm{s}^{1}\right) 1981-2010$ & 280.5 & 650.0 & 1050.6 \\
\hline $\mathrm{SQ}\left(\mathrm{m}^{3} \cdot \mathrm{s}^{1}\right) 1991-2010$ & 281.1 & 627.5 & 1075.7 \\
\hline$\Delta Q(\mathrm{SQ1961}-90 / \mathrm{SQ1931-60)} \%$ & $-4.7 \%$ & $-2.3 \%$ & $-6.3 \%$ \\
\hline$\Delta Q(\mathrm{SQ1981}-2010 / \mathrm{SQ1931-60)} \%$ & $-12.9 \%$ & $-17.8 \%$ & $13.3 \%$ \\
\hline$\Delta Q(\mathrm{SQ1991}-2010 / \mathrm{SQ1931-60}) \%$ & $-12.7 \%$ & $-20.6 \%$ & $-11.2 \%$ \\
\hline$\Delta Q(\mathrm{SQ1981-2010/SQ1961-90)} \%$ & $-8.6 \%$ & $-15.8 \%$ & $-7.4 \%$ \\
\hline$\Delta Q(\mathrm{SQ1991-2010/SQ1961-90)} \%$ & $-8.4 \%$ & $-18.8 \%$ & $-5.2 \%$ \\
\hline
\end{tabular}

Source: Meteorological and Hydrological Service of Croatia.

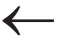

Fig. 3. Mean, maximum and minimum annual discharges at the hydrological stations Rugvica, Jasenovac and Županja in the middle course of the Sava River in the 1931-2010 period Source: Meteorological and Hydrological Service of Croatia. 
the Sava River and so its discharge regime is more stable and maximum discharges cannot be as much under influence of intensive but spatially limited precipitations.

The presented trends in characteristic annual discharges in the Sava River middle course in 1931-2010 are in accordance with the results of previous research and with published analyses of climate changes in Croatia and Bosnia and Herzegovina. According to the Fifth National Communication of the Republic of Croatia under the United Nation Framework Convention on the Climate Change (Branković et al. 2009) at meteorological stations in Croatia there is an observed increase of the mean air temperature during the 20th century for 0.2 to $0.7^{\circ} \mathrm{C}$, and this keeps going on and at higher rates at the beginning of the 21th century. Similar results are found in the Second National Communication of Bosnia and Herzegovina under the United Nations Framework Convention on Climate Change (SNC expert team and Project board, 2013). Besides raising air temperatures in Croatia there is generally a positive trend of potential and real evapotranspiration as well as a negative trend in runoff values in almost all of Croatia (Pandžić et al. 2009). Concerning annual precipitation in Croatia, since the beginning of the 20th century a negative trend is observed (Gajić-Čapka, Cindrić 2011). Šegota and Filipčić (2007) concluded that there is a significant correlation between negative precipitation trend in Ljubljana in Slovenia with decreasing the Sava River flow at Zagreb station. The aforementioned climate changes in the Sava River basin crucially influenced the decending trends of mean annual discharges at all three hydrologic stations in the Sava River middle course in the 1931-2010 period. It is proper to mention that the river discharge regime is a very stable component of the hydrological cycle, meaning that relatively deep changes are needed before they can reflect upon it, and when they occur then long-time series analysis of discharge values can provide valuable information about trends and variations of the climate elements of the referring area (Chiew, McMahon 1996).

At all three hydrologic stations, there is a notable cyclic variation of mean annual discharges during the whole 1931-2010 period (Fig. 3). The cyclic variation can also be observed in the annual maximum and minimum discharge time series at all three stations. This is illustrated in fig. 4 in the case of the hydrological station Jasenovac, where instead of a linear trend line there is a polynomial trend curve fitted to the mean annual discharges time series. The polynomial trend curve even better fits the data $\left(\mathrm{R}^{2}=0.29\right.$ for the polynomial curve compared to the $\mathrm{R} 2=0.12$ for the linear trend line, although the coefficient of determination is low in both cases). This cyclic variation is attuned on all three stations, meaning it is not a case of random occurrence at one place. It is reasonable to assume that the cyclic variation in mean annual discharges in the Sava River middle course is related to the cyclic variations in the annual precipitation long term series (Fig. 4) in the region as already scientifically described in some previous climatological research (Gajić-Čapka 1994; Pandžić et al. 2009; Filipčić et al. 2012, 2013). 

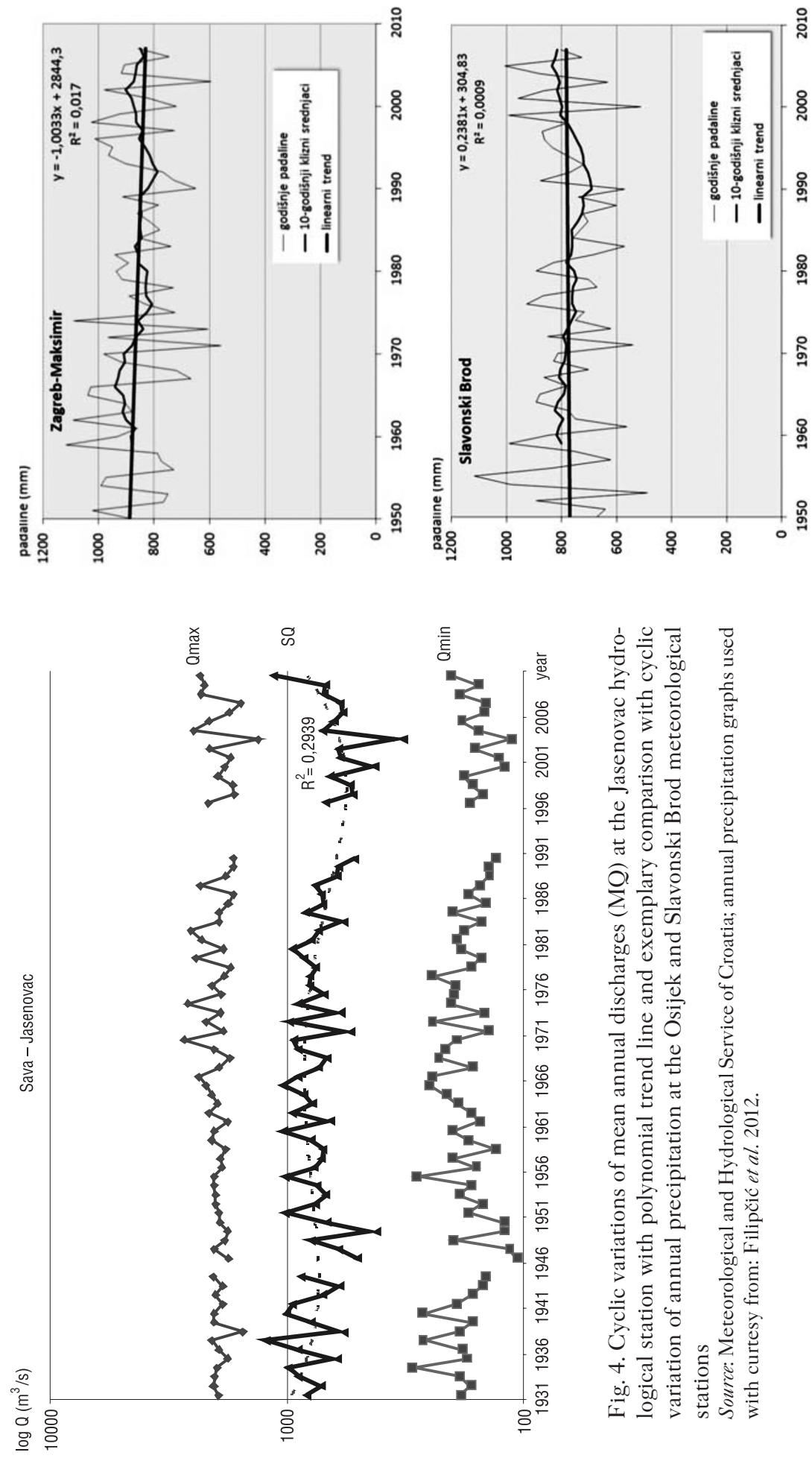

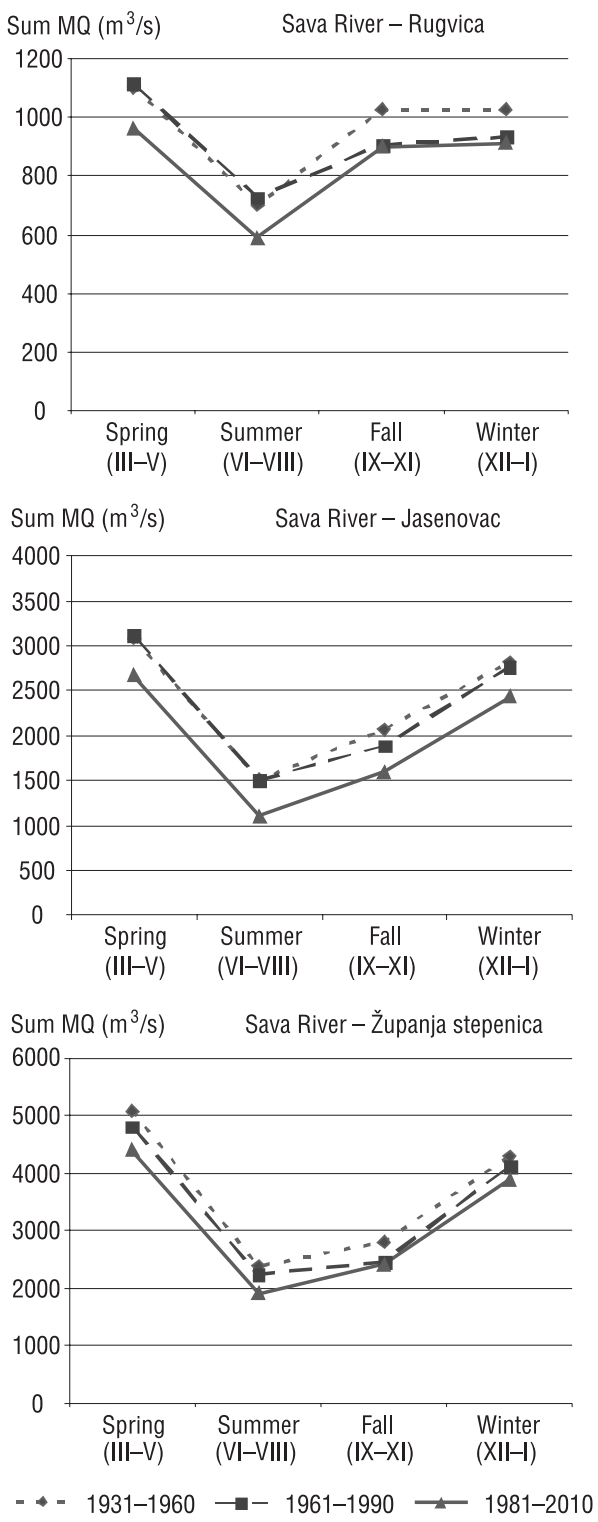

Fig. 5. Summary seasonal discharges for selected periods at the hydrological stations Rugvica, Jasenovac and Županja in the middle course of the Sava River

Source: Meteorological and Hydrological Service of Croatia.
After it has been established that at all three selected stations there is a decrease in mean annual discharges, an observation of seasonal changes is in order. Fig. 5 presentsdischarges in the form of seasonal sums of monthly mean values for the 30 -year periods being compared. It is obvious that a decrease in all seasons occurred if we compare the first and the last (contemporary) period. But this decrease was not equal throughout the time frame 1931-2010. First, at all stations in the 1961-1990 period there is a decrease of discharge in absolute values practically only in the fall season (at the Rugvica station more notable also in the winter season). In the contemporary 1981-2010 period a noticeable decrease followed in all other seasons, spring, summer and winter.

Observing relative data on seasonal discharges in the form of percentage annual (Tab. 6) some new conclusions follow. Contemporary mean seasonal distribution is different from the one from both of the previous climatological standard reference periods.

The fall season discharge decrease has led to the seasonal redistribution in 1961-1990 compared to the previous climatological reference period so that at all three stations there is a drop of the fall season share of annual discharge. In the contemporary 30-year period 1981-2010, compared to the previous climatological reference period, at all three stations there is a drop of the summer season share of annual discharge (at Rugvica also a drop of the spring share). 
Table 6. Annual shares (\%) of the mean seasonal discharges for selected periods at the hydrological stations Rugvica, Jasenovac and Županja in the middle course of the Sava River

\begin{tabular}{|c|c|c|c|c|}
\hline & $\begin{array}{l}\text { Spring } \\
\text { (III-V) }\end{array}$ & $\begin{array}{l}\text { Summer } \\
\text { (VI-VIII) }\end{array}$ & $\begin{array}{c}\text { Fall } \\
(I X-X I)\end{array}$ & $\begin{array}{l}\text { Winter } \\
\text { (XII-II) }\end{array}$ \\
\hline \multicolumn{5}{|c|}{ Rugvica } \\
\hline SQ \% 1931-1960 & $28.61 \%$ & $18.18 \%$ & $26.62 \%$ & $26.59 \%$ \\
\hline SQ \% 1961-1990 & $30.28 \%$ & $19.74 \%$ & $24.64 \%$ & $25.33 \%$ \\
\hline SQ \% 1981-2010 & $28.61 \%$ & $17.51 \%$ & $26.73 \%$ & $27.15 \%$ \\
\hline SQ \% 1991-2010 & $26.49 \%$ & $15.04 \%$ & $29.10 \%$ & $29.37 \%$ \\
\hline \multicolumn{5}{|c|}{ Jasenovac } \\
\hline $1931-1960$ & $32.54 \%$ & $15.90 \%$ & $21.82 \%$ & $29.74 \%$ \\
\hline 1961-1990 & $33.55 \%$ & $16.29 \%$ & $20.35 \%$ & $29.81 \%$ \\
\hline 1981-2010 & $34.20 \%$ & $14.12 \%$ & $20.45 \%$ & $31.22 \%$ \\
\hline 1991-2010 & $32.04 \%$ & $12.62 \%$ & $21.61 \%$ & $33.74 \%$ \\
\hline \multicolumn{5}{|c|}{ Županja stepenica } \\
\hline $1931-1960$ & $34.88 \%$ & $16.38 \%$ & $19.26 \%$ & $29.47 \%$ \\
\hline $1961-1990$ & $35.27 \%$ & $16.37 \%$ & $18.09 \%$ & $30.26 \%$ \\
\hline $1981-2010$ & $34.87 \%$ & $15.13 \%$ & $19.18 \%$ & $30.83 \%$ \\
\hline $1991-2010$ & $32.80 \%$ & $14.51 \%$ & $20.31 \%$ & $32.38 \%$ \\
\hline
\end{tabular}

Source: Meteorological and Hydrological Service of Croatia.

If we compare the seasonal discharge distributions in the first and last 30-year periods, contemporary time distribution is again similar to the one from 1931-1960, but it is also true that all three stations the summer season shares are lower in the 1981-2010 period. If instead of the 30-year period (1981-2010) we take a look at the distribution in the 20-year contemporary period (avoiding time-series overlapping) the summer discharge share has even more decreased and besides we can conclude that in the two decades 1991-2010 spring season share of annual discharge also dropped. The data for Rugvica are again somewhat different as there we observe an increase of the fall season share to the point of levelling up to the winter season share of annual discharge and this is not the case for other two downstream stations.

The decrease of the discharge in the warmer part of the year in the Sava River middle course is the most important result corresponding to previous research of climate changes in the region, especially with the trend of rising air temperatures and with the increasing evapotranspiration.

Finally the changes of discharge regimes have to be observed in more detail by comparing the anual courses of the mean monthly discharges at the selected stations 
for each of the climatological standard reference periods and for the contemporary 30-year period (Fig. 6).

Let us first look at the characteristics of the discharge regimes in the initial 1931-1960 period. Concerning regime types the situation in the Sava River middle course was same as today; at the Rugvica station the Sava had the typical Peripannonian pluvial-nival regime, at Jasenovac there are some transitional characteristics towards the Panonnian regime type and at Županja the Sava had a Panonnian pluvial-nival discharge regime. However, both maximums occurred differently in the 1931-1960 regimes than nowadays. The spring time maximum in the annual course of mean monthly discharges was in March and it was less prominent compared to the next two following spring months. The chart line of annual course of monthly modular coefficients (Fig. 6) at all three stations but especially in the case of the Rugvica station is illustrating relative abundance in runoff during late spring and even early summer. The secondary maximum in the annual course of mean monthly discharges was in November, and its prominence in comparison to December mean discharge lessened downstream as well as its modular coefficient. November maximum was well distinguished at Rugvica (with Mk = 1.5), at the beginning of the Sava River middle course, while at Županja, near the end of its middle course, November and December values where equalised (Tab. 3).

Changes occured in the following 1961-1990 period and some of them, like the positions of maximums in the annual course of mean monthly discharges, have remained changed since then to nowadays. We already mentioned that the annual discharge decreased, so most of the months have lower absolute discharge values (Fig. 6). We also mentioned that at the seasonal level in that period at all three stations the fall season discharge dropped. According to the annual course of mean monthly discharges (Fig. 6) it is obvious that it was almost entirely due to a significant decrease in November, absolutely (in $\mathrm{m}^{3} \mathrm{~s}^{-1}$ ) and relatively (in modular coefficients $\mathrm{Mk})$. Although a continuous stagnation or decrease of mean monthly discharge values is noted at all three stations from October to March it cannot be compared in intensity to the decrease of mean discharge in November. The December values thus dropped so much less than in November that in the annual course of mean monthly discharges November maximum in most of the Sava River middle course (stations Jasenovac and Županja) jumped to December. In the same period (1961-1990) in the entire middle course of the Sava there was a shift in the spring time maximum, from March to April. March mean discharge values decreased absolutely and relatively while at the same time April values increased both ways partly compensating March losses, so as both months are in spring season the shift did not significantly change spring season annual discharge share. At all three stations during primary minimum in mean monthly discharges course, a mild increase in absolute values is noticed at Rugvica and Jasenovac in August and both neighbouring months and at $\check{Z}$ upanja 

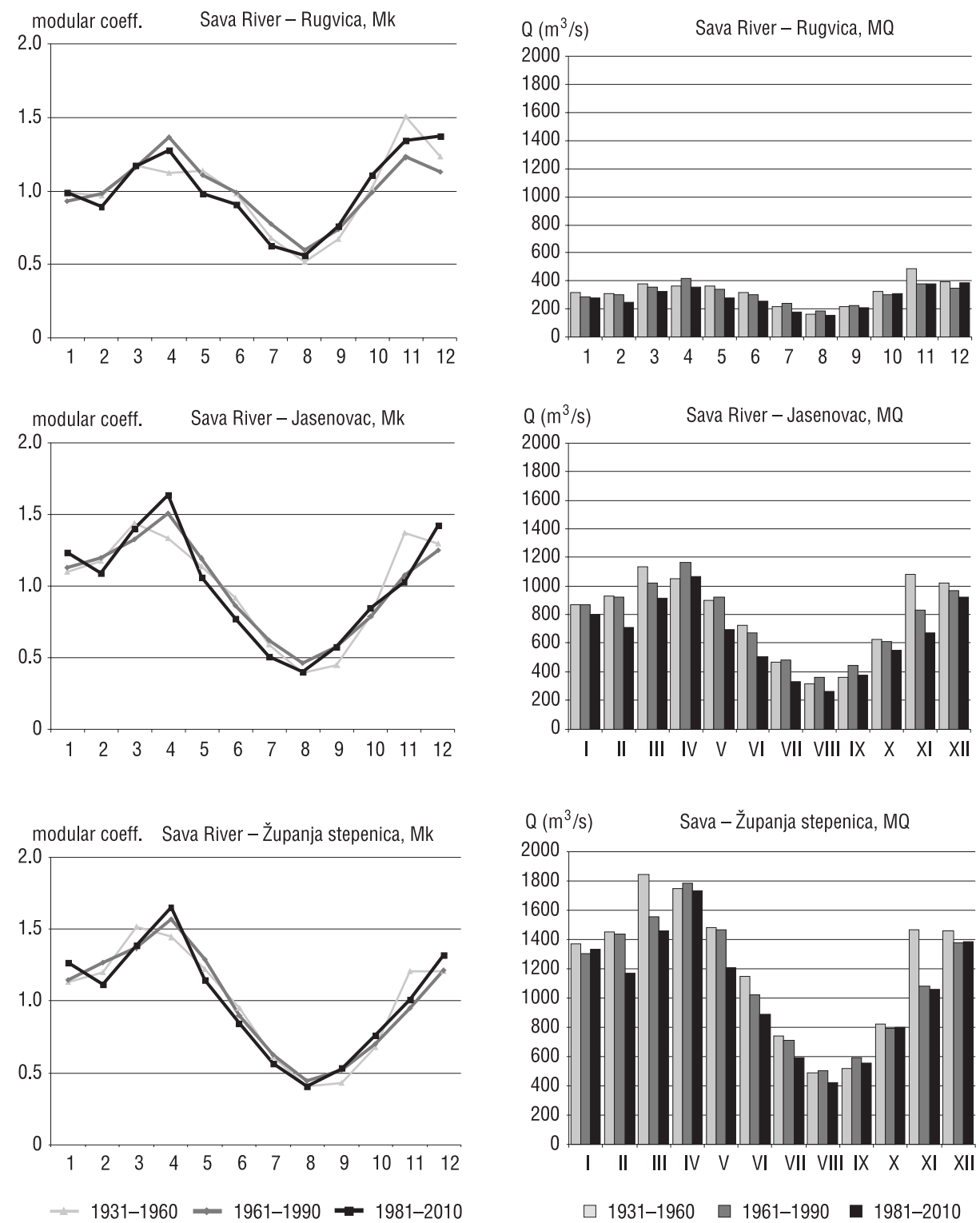

Fig. 6. Comparison of discharge regimes for selected periods at the hydrological stations Rugvica, Jasenovac and Županja in the middle course of the Sava River Source: Meteorological and Hydrological Service of Croatia. 
August and September which is reflected in mildly higher modular coefficients too. It is also interesting to notice that that in the 1961-1990 period at all three stations the spring time maximum, in April, was the primary maximum, which means that at the Rugvica station the Peripannonian pluvial-nival regime characteristics weakened, however in the case of Rugvica the April modular coefficient was not sufficiently high as to change the regime type to the Panonnian pluvial-nival discharge regime type and to turn the whole Sava River middle course to it.

The aforementioned changes of the discharge regimes in the Sava River middle course in the 1961-1990 period in relation to the previous 1931-1960 period can be at least in part explained by some of the climate changes determined in relevant research. The significant decrease of November discharge corresponds with a marked decrease of precipitation in the previous month of October, according to the research of long-time changes in the precipitation regime in the region (notably: Penzar, Penzar 1979, 1981; Juras,1985). Moreover, October is the leading month in precipitation variability in Croatia (Maradin 2007). The transfer of the spring time discharge maximum from March (the Sava River middle course discharge regimes 1931-1960) to April (the Sava River middle course discharge regimes 1961-1990) needs additional investigation. However, the precipitation regime in the mountainous Dinaric area in Croatia (and possibly in parts of Bosnia and Herzegovina) belonging to the Sava River catchment could be of influence on the spring time discharge maximum in the Sava River middle course. Namely, the April rainfall maximum is characteristic for the precipitation regime in the Dinaric part of Croatia and it is related to the wave cyclones that at that time move inland from the Adriatic Sea (Penzar and Penzar, 1981). The spring time discharge maximum is naturally connected to the spring time snow melting, too. In the discharge regimes in the Sava River middle course for the 1931-1960 climatological standard referent period presented in Parde modular coefficients (Fig. 6) the March maximums where not so prominent to later months, or, in other words, the monthly modular coefficients fell relatively gradually from March to June. It is known that in the region, the snow share in total precipitation decreased and the snow cover duration shortened during the 20th century (notably: Branković et al. 2009; Gajić-Čapka 2011; SNC expert team and Project Board 2013) so it can be hypothesised that in the 1961-1990 period there was less snow melt that in the previous period (1931-1960) when more abundant snow melt could have been more steadily filling up the groundwater which in turn could have been feeding stream flows in the Sava River basin for a prolonged time during spring season. Less snowmelt in the later period could have emphasised the more direct influence of April rainfalls in the Dinaric Croatia on discharge regimes, influencing the higher April modular coefficient values in the Sava River middle course, especially after it receives the Kupa River which receives much of its headwaters from the Dinaric part of Croatia. 
The contemporary 30-year period 1981-2010 is characterised by the continued discharge decrease of annual values as well as of most mean monthly values at selected stations in the Sava River middle course. At the Jasenovac station all months have lower mean monthly discharges than in the 1961-1990 climatologic standard reference period, and at Rugvica and Županja only two months have about the same and somewhat increased mean monthly discharges, both in winter. At the Rugvica station, the only one that in 1961-1990 period retained the late fall - early winter maximum in annual course of mean monthly discharges in November, in contemporary period the late fall - early winter maximum moved from November to December. Besides this maximum at Rugvica in the 1981-2010 period again became primary, thus strengthening the Peripanonnian discharge regime type characteristics. On Fig. 6 there are no time series for the 20-year period 1991-2010, as the differences to the 30-year period 1981-2010 are seasonal and already discussed (Fig. 2; Tab. 3) whereby it was concluded that in the 30 -year contemporary period there is a decrease in the summer season share of annual discharge compared to previous periods, and with the 20-year period besides significant decrease of summer season share of annual discharge there is also a decrease in the spring season share, so altogether in more recent times the warmer part of the year has less share in annual discharge.

There is no doubt that the main change of the Sava River middle course discharge regimes in the contemporary period, the decrease of the summer and spring share in annual discharge, is well connected to the accelerated rise of mean annual and monthly air temperatures, to the increase in potential and real evapotranspiration and to the negative trend of runoff in almost whole of the Croatia (Pandžić et al. 2009). Furthermore, the recent research of precipitation changes (Gajić-Čapka et al. 2014) prove that in the 1961-2010 period there is a significant decrease in summer month precipitation amounts in all of Croatia and especially in the Dinaric part of Croatia (at a rate of $-20 \mathrm{~mm}$ per decade); in the Dinaric part, there is also less precipitation in spring and even in fall months. This is important as the Sava River basin in large part extends to the Dinarides. Most of the Dinaric part of the Sava River basin lies in Bosnia and Herzegovina. In Bosnia and Herzegovina, climate changes where addressed in the Second National Communication of Bosnia and Herzegovina under the UNFCGC (SNC expert team and Project Board 2013) and the contemporary 1981-2010 period data where compared to the previous climatologically standard reference 1961-1990 period data. As in Croatia an increase of annual air temperatures was confirmed (at rates of 0.4 to $0.8^{\circ} \mathrm{C}$ annually). In general, there are no significant changes in annual precipitation amounts, but a decrease in the number of days with precipitation over $1.0 \mathrm{~mm}$ and simultaneously an increase in the number of days with severe precipitation were observed. The report specifies that the redistribution of precipitation in the annual course of monthly amounts is, together with air temperature rising, effectively causing more frequent and more 
intensive dry spells as well as floods in Bosnia and Herzegovina. The report states that in the future less precipitation amounts are expected in the whole country, especially in the summer season.

\section{Conclusions}

To analyse discharge regimes in the middle course of the Sava River three hydrologic stations were chosen having homogenous and as much continuous data on river discharge in the observed period 1931-2010. Those stations are Rugvica at the beginning of the middle Sava, the Jasenovac station positioned just forehead of the Una river mouth and all the other large tributaries from Bosnia and Herzegovina and the $\check{Z}$ upanja station near the end of the middle Sava river course.

There are statistically significant descending trends of mean annual discharges at all three hydrologic stations in the middle course of the Sava River in the 1931-2010 period. The minimum annual discharges are also descending (statistically significant on Rugvica), which is worrying. At the same time the maximum annual discharges are ascending at the Rugvica station, which is unfavourable. An all three hydrologic stations, there is a notable cyclic variation of mean annual discharges during the whole period, which can be linked to researched cyclic variations of precipitation in the region.

In comparison of river discharge regimes from the climatological standard reference periods 1931-1960 and 1961-1990 as well as from the latest 30-year period 1981-2010 it is noted that important changes in the yearly course of the mean monthly discharges already occurred in the 1961-1990 period. At the seasonal level in that period at all three selected stations there is a significant decrease of the autumn share in annual discharge. In the annual course of mean monthly discharges the secondary maximum in the part of the Sava River downstream of the Kupa tributary mouth transferred from November to December. The significant reduction of November discharges is in part caused by the significant long-time decrease of precipitation in October. At all three stations in the Sava River middle course there was a shift in the spring time maximum, from March to April and it can be hypothesised that this is in part caused by diminishing role of snowmelt in regenerating groundwater and by the more direct runoffs of March rains, typical in mountain part of Croatia.

The contemporary period is characterised by a continuation of the decrease of mean annual and monthly discharges and particularly by a significant decrease of the summer share in annual discharge. In the recent 20-year period 1991-2010, compared to previous climatological standard periods there is a significant decrease in the share of annual discharge not only in summer but also in spring months, 
i.e. in the warmer part of the year. The analysed changes in the discharge regimes are linked in almost all of Croatia.

In conclusion, the changes in the river discharge regimes in the middle course of the Sava River in the 1931-2010 period are predominantly linked to the scientifically observed climate changes. In general, the observed river discharge regime changes are hydrologically unfavourable and should be considered in all aspects of water management, especially given that most likely current discharge trends will continue in accordance to predicted future climate change (warming) in the region (the Sava River basin).

\section{References}

Agencija za vodno područje rijeke Save, 2016, Sava River basin water management plan in Federation of Bosnia and Heræegovina 2016-2021 / Nacrt Plana upravljanja vodama \&a vodno područje rijeke Save u Federaciji Bosne i Hercegovina 2016-2021, Sarajevo, 150 pp, The digital version of this document is available at: http://www.voda.ba/nacrt-plana-upravljanjavodama-za-vodno-podrucje-save-i-prateci-dokumenti.

Arnel N., 2002, Hydrology and Global Environmental Change, Pearson Education Ltd., Harlow, England, UK, pp. 346 (1sted.).

Beckinsale R.P., 1969, River regimes, [in:] R.J. Chorley (ed.), Water, Earth and Man, Methuen, London,176-192.

Bezak N., Brilly M., Šraj M., 1916, Flood frequency analyses, statistical trends and seasonality analyses of discharge data: a case study of the Litija station on the Sava River, Journal of Flood Risk Management, 9 (2), 154-168.

Bonacci O., 2014, Hidrološka analiza mjerenja izvršenih na vodomjernoj postaji Slavonski Brod na rijeci Savi, Hrvatske vode, 22 (89), 267-272.

Bonacci O., Trninić D., 1991, Hydrologische, durch die Aktivität des Menschen hervorgerufene Veränderungen im Flussgebiet der Sava bei Zagreb, Wasserwirtschaft, 81 (4), 171-175.

Bonacci O., Ljubenkov, I., 2003, Procjena sigurnosti Zagreba od poplava vodama rijeke Save u novim uvjetima, Hrvatska Vodoprivreda, 12 (127-128), 51-55.

Bonacci O., Ljubenkov I., 2004, Statistička analiza maksimalnih godišnjih protoka Save kod Zagreba u razdoblju 1926-2000, Hrvatske vode, 12 (48), 243-252.

Bonacci O., Ljubenkov I., 2008, Changes in flow conveyance and implication for flood protection, Sava River, Zagreb, Hydrological Processes, 22 (8), 1189-1196.

Branković Č., Cindrić K., Gajić-Čapka M., Güttler I., Patarčić M., Vučetić V., Zaninović K., 2009, Fifth National Communication of the Republic of Croatia under the United Nation Framework Convention on the Climate Change (UNFCCC). Selected chapters: Observed climate changes in Croatia Climate change scenario, Impact of climate variations and changes on plants and wildfire danger, DHMZ, Zagreb, 46 pp. The digital version of this document is available at: http:// klima.hr/razno/publikacije/climate_change.pdf. 
The digital version of full document (published by Ministry of Environmental Protection, Physical Planning and Construction, 2010, Zagreb, 215 pp) is available at:

http://klima.mzoip.hr/default.aspx?id=271

Chiew F.H.S., McMahon T.A., 1996, Trends in Historical Streamflow Records, [in:] J.A.A. Jones, C. Liu, M.-K. Woo, H.-T. Kung (eds.), Regional Hydrological Response to Climate Change, Kluwer Academic Publishers, Dordrecht, Nedherlands, 63-68.

C̆anjevac I., 2012, Novije promjene protočnih rě̌ima u hrvatskom dijelu poriječja Dunava, Hrvatski geografski glasnik, 74 (1), 71-74.

Čanjevac I., 2013, Tipologija protočnih rě̌ima rijeka u Hrvatskoj, Hrvatski geografski glasnik, 75 (1), 23-42.

Čanjevac I., Orešić D., 2015, Contemporary changes of mean annual and seasonal river discharges in Croatia, Hrvatski geografski glasnik, 77 (1), 7-27.

Federal Ministry of Agriculture, Water Management and Forestry, The Sava River Basin District Agency, The Adriatic Sea River Basin District, 2012, Water management strategy of the Federation of Bosnia and Herzegovina / Strategija upravljanja vodama Federacije Bosne $i$ Hercegovine 2010-2022, Sarajevo, 306 pp. The digital version of this document in English language is available at: http://fmpvs.gov.ba/upload_files/1440490897-276_1090_1675_e.pdf.

Federalni hidrometeorološki zavod i Zavod za vodoprivredu d.d. Sarajevo, 2012, Hidrološka studija površinskih voda Bosne i Hercegovine - sliv rijeke Bosne, Glavna knjiga, Sarajevo, 50 pp.

Filipčić A., Orešić D., Maradin M., 2012, Influence of the continentality on long-term precipitation trends in Croatia, Acta geographica Croatica, 38, 15-24.

Filipčić A., Orešić D., Maradin M., 2013, Changes in precipitation levels in Croatia from the mid $20^{\text {th }}$ century to the present, Geoadria, 18 (1), 29-39.

Frantar P., 2003, Pretočni rě̌imi na reki Savi in njihove spremembe med obdobjem 1961-90 in 1991-2000, [in:] 14. Mišičev vodarski dan 2003 - zbornik, Maribor (Slovenia), December 5th 2003, Vodnogospodarski biro, Maribor, pp. 133-141.

Frantar P., 2005, Pretočni režimi slovenskih rek in njihova spremenljivost, Ujma, 19, 145-153.

Frantar P., Hrvatin M., 2005, Pretočni rě̌imi v Sloveniji med letoma 1971 in 2000, Geografski vestnik, 77 (2), 115-127.

Gajić-Čapka M., 1994, Periodicity of annual precipitation in different climate regions of Croatia, Theoretical and Applied Climatology, 49 (4), 213-216.

Gajić-Čapka M., 2011, Snow climate baseline conditions and trends in Croatia relevant to winter tourism, Theoretical and Applied Climatology, 105 (1), 181-191.

Gajić-Čapka M., Cindrić K., 2011, Secular trends in indices of precipitation extremes in Croatia, 1901-2008, Geofizika, 28 (2), 293-312.

Gajić-Čapka M, Cindrić K., Pasarić Z., 2014, Trends in precipitation indices in Croatia, 1961-2010, Theoretical and Applied Climatology, 121 (1-2), 167-177.

Hagemann S., Chen C., Clark D.B., Folwell S., Gosling S.N., Haddeland I., Hanasaki N., Heinke J., Ludwig F., Voss F., Wiltshire A.J., 2013, Climate change impact on available water resources obtained using multiple global climate and hydrology models, Earth System Dynamics, 4, 129-144. 
Hartmann D.L., Klein Tank A.M.G., Rusticucci M., Alexander L.V., Brönnimann S., Charabi Y.A.-R., Dentener F.J., Dlugokencky E.J., Easterling D.R., Kaplan A., Soden B.J., Thorne P.W., Wild M., Zhai P., 2013, Observations: Atmosphere and Surface, [in:] T.F. Stocker, D. Qin, G.-K. Plattner, M. Tignor, S.K. Allen, J. Boschung, A. Nauels, Y. Xia, V. Bex, P.M. Midgley (eds.), Climate Change 2013: The Physical Science Basis. Contribution of Working Group I to the Fifth Assessment Report of the Intergovernmental Panel on Climate Change, Cambridge University Press, Cambridge, UK - New York, NY, USA, 159-254.

ISRBC, group of authors, 2010, Sava River Basin Analysis Summary, International Sava River Basin Commission, Zagreb, 33 pp. The digital version of this document is available at: http://www.savacommission.org/dms/docs/dokumenti/documents_publications/publications/sava_river_basin_analysis_-_summary/sava_booklet_eng.pdf.

ISRBC, group of authors, 2013a, Sava River Basin Management Plan, International Sava River Basin Commission, Zagreb, 126 pp +13 annexes. The digital version of this document is available at: http://www.savacommission.org/srbmp/en/draft.

ISRBC, group of authors, 2013b, Estimation of Sediment Balance for the Sava River. International Sava River Basin Commission, Zagreb, 12 pp. The digital version of this document is available at http://www.savacommission.org/dms/docs/dokumenti/documents_publications/publications/other_publications/sediment_booklet/booklet_sediment_balance_en.pdf.

ISRBC, group of authors, 2014, Priručnik za plovidbu na rijeci Savi / Manual for Navigation on the Sava River, (ed. board D. Komatina, Ž. Milković, D. Isaković, G. Šukalo), International Sava River Basin Commission, Zagreb, 208 pp. The digital version of this document is available at: http://www.savacommission.org/dms/docs/dokumenti/documents_publications/publications/navigation_publication/prirucnik_za_plovidbu_na_rijeci_savi/e_ prirucnik_za_plovidbu_na_rijeci_savi_latinica.pdf.

JU Vode Srpske, 2015, Strategija integralnog upravljanja vodama Republike Srpske 2015-2024, godine, Banja Luka, 315 pp. The digital version of this document is available at: http://www.voders. org/images/Strategija\%20integralnog\%20upravljanja\%20vodama\%20RS\%202015-2024.pdf.

Juras J., 1985, Neke karakteristike promjene klime Zagreba u posljednjem tridesetljeću, Geofizika, 2, 93-102.

Korjenić A., 2014, Basic characteristics water regime and water balance of the river Una, Acta geographica Bosniae et Herzegovinae, 2, 65-75.

Kratofil L., 2000, Promjene vodnog rě̌ima Save usrokovane ljudskom djelatnošću, [in:] D. Trninić (ed), Zbornik radova okruglog stola: Hidrologija i vodni resursi Save u novim uvjetima, Slavonski Brod (Croatia), 7-8 November 2000, Hrvatsko hidrološko društvo, Zagreb, 335-352.

Lawrence D., Andersen T., Haddeland I., 2009, Climate Change and Changing Runoff in South East Europe, [in:] Report on the Statkraft workshop, Belgrade, 26-27 May, 2009, Statkraft Development AS, Norwegian Water Resources and Energy Directorate (NVE), Utgitt i Oppdragsrapportserie A i 2009, Oppdragsrapport A15, 29.

Maradin M., 2007, Varijabilnost padalina u Osijeku, Hrvatski geografski glasnik, 69 (2), 53-77. 
Orešić D., 2008, Zagreb - grad na Savi?, [in:] Geografija. hr offline 1, printed edition of the portal www.geografija.hr, HGD, Zagreb, 10-14, http://www.geografija.hr/hrvatska/zagrebgrad-na-savi/.

Pandžić K., Trninić D., Likso T., Bošnjak T., 2009, Long-term variations in water balance components for Croatia, Theoretical and Applied Climatology, 95, 39-51.

Penzar B., Penzar I., 1979, O poloæ̌aju i uzrocima ekstrema u godišnjem hodu oborine u Hrvatskoj, Dio I: Hrvatski geografski glasnik, 41-42 (1), 27-48.

Penzar B., Penzar I., 1981, O poloæ̌aju i usrocima ekstrema u godišnjem hodu oborine u Hrvatskoj, Dio II: Hrvatski geografski glasnik, 43 (1), 27-49.

Riđanović J., 1983, Hidrogeografske značajke SR Hrvatske, Hrvatski geografski glasnik, 45 (1), $33-41$.

Riđanović J., 1993, Hidrogeografija, Školska knjiga, drugo izmj. i dopunj. izdanje, Zagreb.

Stahl K., Hisdal H., Hannaford J., Tallaksen L.M., van Lanen H.A.J., Sauquet E., Demuth S., Fendekova M., Jodar J., 2010, Streamflow trends in Europe: Evidence from a dataset of near-natural catchments, Hydrology and Earth System Sciences, 14, 2367-2382.

Stahl K., Tallaksen L.M., Hannaford J., van Lanen H.A.J., 2012, Filling the white space on maps of European runoff trends: estimates from a multi-model ensemble, Hydrology and Earth System Sciences, 16, 2035-2047.

SNC expert team and Project Board (group of authors), 2013, Second National Communication of Bosnia and Herzegovina under the United Nations Framework Convention on Climate Change, Ministry of Foreign Trade and Economic Relations of Bosnia and Herzegovina; Federal Ministry of Environment and Tourism; Republic of Srpska Ministry for Spatial Planning, Civil Engineering and Ecology; Brčko District Government; United Nations Development Programme in Bosnia and Herzegovina, 194 pp. The digital version of this document is available at: http://www.ba.undp.org/content/bosnia_and_herzegovina/en/home/library/ environment_energy/sncbih-2013.html.

Šegota T., Filipčić A., 2007, Contemporary climate changes and decrease of Sava river flow through Zagreb, Geoadria, 12 (1), 47-58.

Šterc S., 1979a, Kanal Sava - Odra - Sava kao objekt obrane Zagreba od poplava, Hrvatski geografski glasnik, 41-42 (1), 97-115.

Šterc S., 1979b, Osnovne fizičko-geografske karakteristike savskog porječja između Radeča i Siska, Acta geographica Croatica, 14 (1), 47-59.

Trninić D., Bošnjak T., 2009, Characteristic discharges of the Sava River at Zagreb, Hrvatske vode, 17 (69/70), 257-268.

Ulaga F., 2002, Trendi spreminjanja pretokov slovenskih rek, Dela, 18, 93-114.

Ulaga F., Kobold M., Frantar P., 2008, Trends of River Discharges in Slovenia, Earth and Environmental Science, 4, 1-13.

Žugaj R., 2015, Hidrologija, Sveučilište u Zagrebu, Rudarsko-geološko-naftni fakultet, 2nd edition, Zagreb, 538 pp. 


\section{Internet sources}

Croatian Encyclopaedia online / Hrvatska enciklopedija mrežno izdanje, Miroslav Krleža Institute of Lexicography, 2017, http://www.enciklopedija.hr (2.02.2017).

ISRBC International Sava River Basin Commission, http://www.savacommission.org/index. php?l-en (2.02.2017).

Proleksis enciklopedija online, Miroslav Krleža Institute of Lexicography, 2013, http://proleksis.lzmk.hr (2.02.2017).

\section{Data sources}

Hydrological Sector of the Federal Hydrological and Meteorological Bureau, Federation of Bosnia and Herzegovina, Bosnia and Herzegovina / Sektor hidrologije Federalnog hidrometeorološkog zavoda $\mathrm{BiH}$, Bosna i Hercegovina (https://www.fhmzbih.gov.ba/latinica/ index.php), Hydrological database, n.d.

Hydrological Sector of the Meteorological and Hydrological Service of Croatia, Croatia / Sektor za hidrologiju Državnoga hidrometeorološkog zavoda RH, Hrvatska (http://hidro. dhz.hr), Hydrological database., n.d.

Hydrological Sector of the Hydrological and Meteorological Bureau of the Republic, Republic of Srpska, Bosnia and Herzegovina / Hidrološko odjeljenje Republičkog hidrometeorološkog zavoda, Republika Srpska, BiH (http://rhmzrs.com), Hydrological database, n.d.

\section{Danijel Orešić}

University of Zagreb

Department of Geography at Faculty of Science

Marulicev trg 19/II, 10000 Zagreb, Croatia (Hrvatska)

doresic@geog.pmf.hr

\section{Ivan Čanjevac}

University of Zagreb

Department of Geography at Faculty of Science

Marulicev trg 19/II, 10000 Zagreb, Croatia (Hrvatska)

canjevac@geog.pmf.hr

\section{Mladen Maradin}

University of Zagreb

Department of Geography at Faculty of Science

Marulicev trg 19/II, 10000 Zagreb, Croatia (Hrvatska)

mmaradin@geog.pmf.hr 
